\title{
Geomorphic features of active faults around the Kathmandu Valley, Nepal, and no evidence of surface rupture associated with the 2015 Gorkha earthquake along the faults
}

Yasuhiro Kumahara ${ }^{*}$, Deepak Chamlagain ${ }^{2}$ and Bishal Nath Upreti ${ }^{3,4}$

\begin{abstract}
The M7.8 April 25, 2015, Gorkha earthquake in Nepal was produced by a slip on the low-angle Main Himalayan Thrust, a décollement below the Himalaya that emerges at the surface in the south as the Himalayan Frontal Thrust (HFT). The analysis of the SAR interferograms led to the interpretations that the event was a blind thrust and did not produce surface ruptures associated with the seismogenic fault. We conducted a quick field survey along four active faults near the epicentral area around the Kathmandu Valley (the Jhiku Khola fault, Chitlang fault, Kulekhani fault, Malagiri fault and Kolphu Khola fault) from July 18-22, 2015. Those faults are located in the Lesser Himalaya on the hanging side of the HFT. Based on our field survey carried out in the area where most typical tectonic landforms are developed, we confirmed with local inhabitants the lack of any new surface ruptures along these faults. Our observations along the Jhiku Khola fault showed that the fault had some definite activities during the Holocene times. Though in the past it was recognized as a low-activity thrust fault, our present survey has revealed that it has been active with a predominantly right-lateral strike-slip with thrust component. A stream dissecting a talus surface shows approximately 7-m right-lateral offset, and a charcoal sample collected from the upper part of the talus deposit yielded an age of $870 \pm 30$ y.B.P, implying that the talus surface formed close to 870 y.B.P. Accordingly, a single or multiple events of the fault must have occurred during the last 900 years, and the slip rate we estimate roughly is around $8 \mathrm{~mm} /$ year. The fault may play a role to recent right-lateral strike-slip tectonic zone across the Himalayan range. Since none of the above faults showed any relationship corresponding to the April 25 Gorkha earthquake, it is possibility that a potential risk of occurrence of large earthquakes does exist close to the Kathmandu Valley due to movements of these active faults, and more future work such as paleoseismological survey is needed to assess the risk.
\end{abstract}

Keywords: 2015 Gorkha earthquake, Active fault, Surface rupture, Tectonic landform, Nepal, Jhiku Khola fault

\section{Introduction}

It became apparent shortly after the M7.8 April 25, 2015, Gorkha earthquake of Nepal that it was a result of thrusting along the Main Himalayan Thrust (MHT) (USGS 2015). The analysis of the SAR interferograms led to the interpretations that the event was a blind thrust and did not produce surface ruptures associated with the

\footnotetext{
*Correspondence: kumakuma@hiroshima-u.ac.jp

${ }^{1}$ Graduate School of Education, Hiroshima University, Higashi-hiroshima, Japan

Full list of author information is available at the end of the article
}

seismogenic fault (Angster et al. 2015; Kobayashi et al. 2015; Lindsey et al. 2015) (Fig. 1). However, continental earthquakes of this size with shallow depth generally produce surface rupture (Wesnousky 2008). This observation served as the initial motivation to a field reconnaissance of the area soon after the event. Our field reconnaissance is guided by the mapping result of active faults and lineament traces along the active surface expression of the Himalayan Frontal Thrust (HFT) (Nakata 1982, 1989; Nakata et al. 1984), and in and around the Kathmandu Valley (Nakata 1982; Yagi et al. 2000; Asahi 2003). Here, we report our findings related to the four faults (Jhiku 


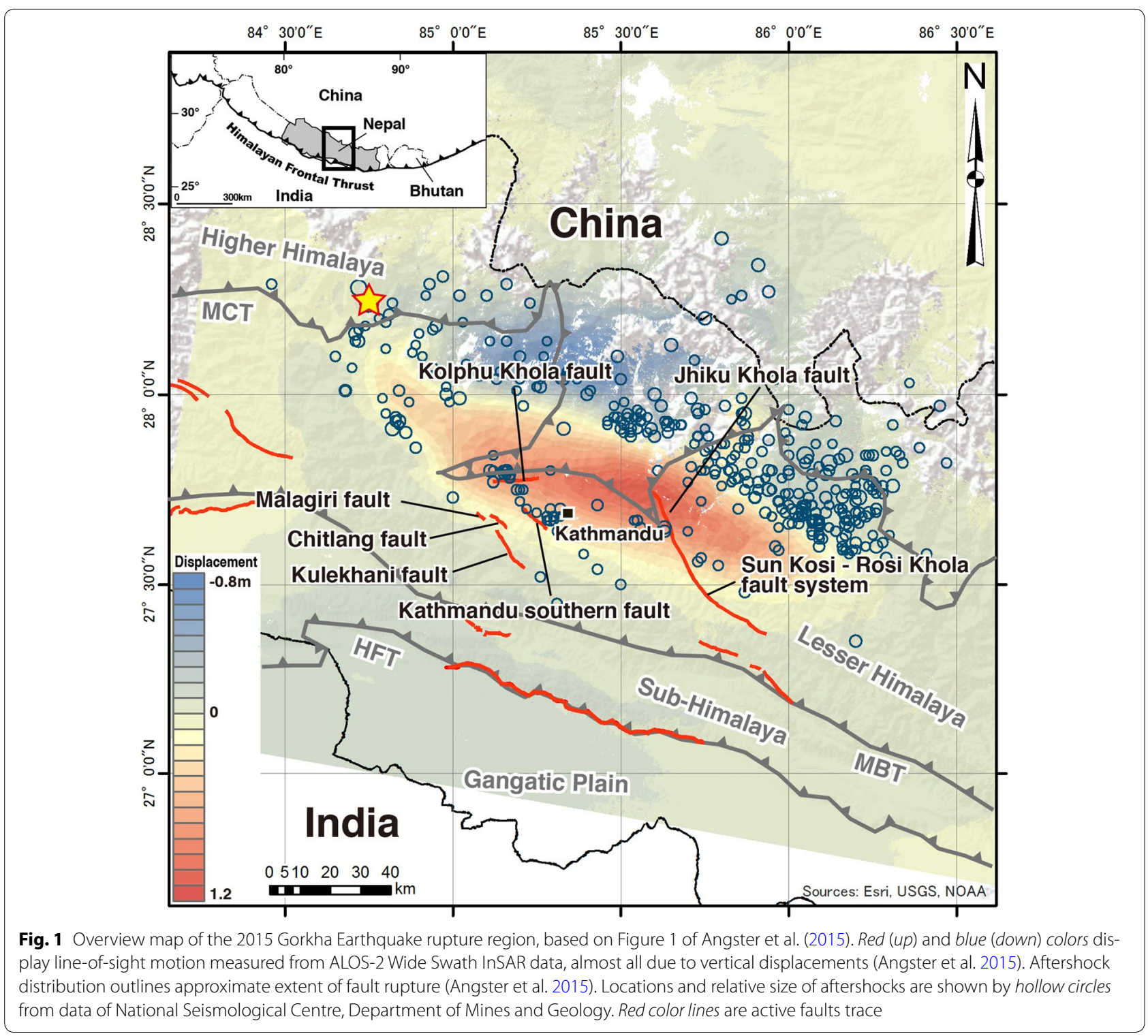

Khola fault (Khola $=$ a stream in Nepali language), Chitlang fault, Kulekhani fault, Malagiri fault and Kolphu Khola fault) around the Kathmandu Valley in the epicentral area based on our brief visit to the area between July 18-22, 2015. Those faults are located in the Lesser Himalaya on the hanging side of the HFT. The results of the survey along the HFT and the Kathmandu southern fault have already been presented by Angster et al. (2015).

\section{Methods}

Our mapping of the tectonic landform and fault traces was based on both of the interpretation of aerial photographs at scales of 1:50,000, and the field survey along the fault. In the field, equipped with the aerial photograph interpretation data, we focused on the study of the nature of tectonic landforms to find the precise location of the fault trace and the evidence of active faulting. We also interviewed local people to find out whether or not some unusual features have developed immediately after the main shock in nearby areas along the trace of the fault, such as surface ruptures and offsets.

Also, we made the detailed digital surface model (DSM) image for the Jhiku Khola fault using the Structure from Motion-Multi-view System (SfM-MVS) software 'Agisoft Photoscan Professional' processing photographs at the different height ranging $10 \mathrm{~m}$ high to the ground level taken by the camera on the tip of the 10 -m-high pole. The camera was connected with a smart phone through $\mathrm{Wi}-\mathrm{Fi}$, and we could monitor the finder view of the camera and shatter by handing the smart phone. Goto (2015) 
developed this technique and confirmed that the accuracy of the DEM using by the technique is equivalent to that of the data measured by the total station.

\section{Results}

\section{Jhiku Khola fault}

The Jhiku Khola fault was recognized by Yagi et al. (2000), who found the strike-parallel bulge, depression and range-facing scarp on the colluvial fan surfaces along the eastern margin of the Panchkhal basin which lies to the east of the Kathmandu Valley. They recognized a NNW-SSE-trending and southwest-dipping thrust fault. Based on the combination of the ${ }^{14} \mathrm{C}$ dating of the fan deposit and vertical displacement caused by the fault, they also concluded that the fault had a relatively slow rate of vertical slip with an average of about
$0.5 \mathrm{~mm} /$ year. Our findings were that the fault extends further north up to Kodari Village situated at the right bank of Indravati River following the left bank of Chu Khola (Fig. 2a, b). The fault is at least $\sim 17 \mathrm{~km}$ long, and the surface trace is well characterized by the strike-parallel bulge, strike-parallel depression, range-facing fault scarp and five stream offsets. The existence of rightlateral stream offsets suggests that it is a right-lateral strike-slip fault with thrust component. Since the southern extension of the fault connects with the northern end of the Sun Kosi-Rosi Khola fault system (Nakata 1982), which is also considered to have a right-lateral strike-slip component, these two faults must represent a continuous single fault system. Below, we described the characteristics of the fault based on the tectonic landforms and geologic features.

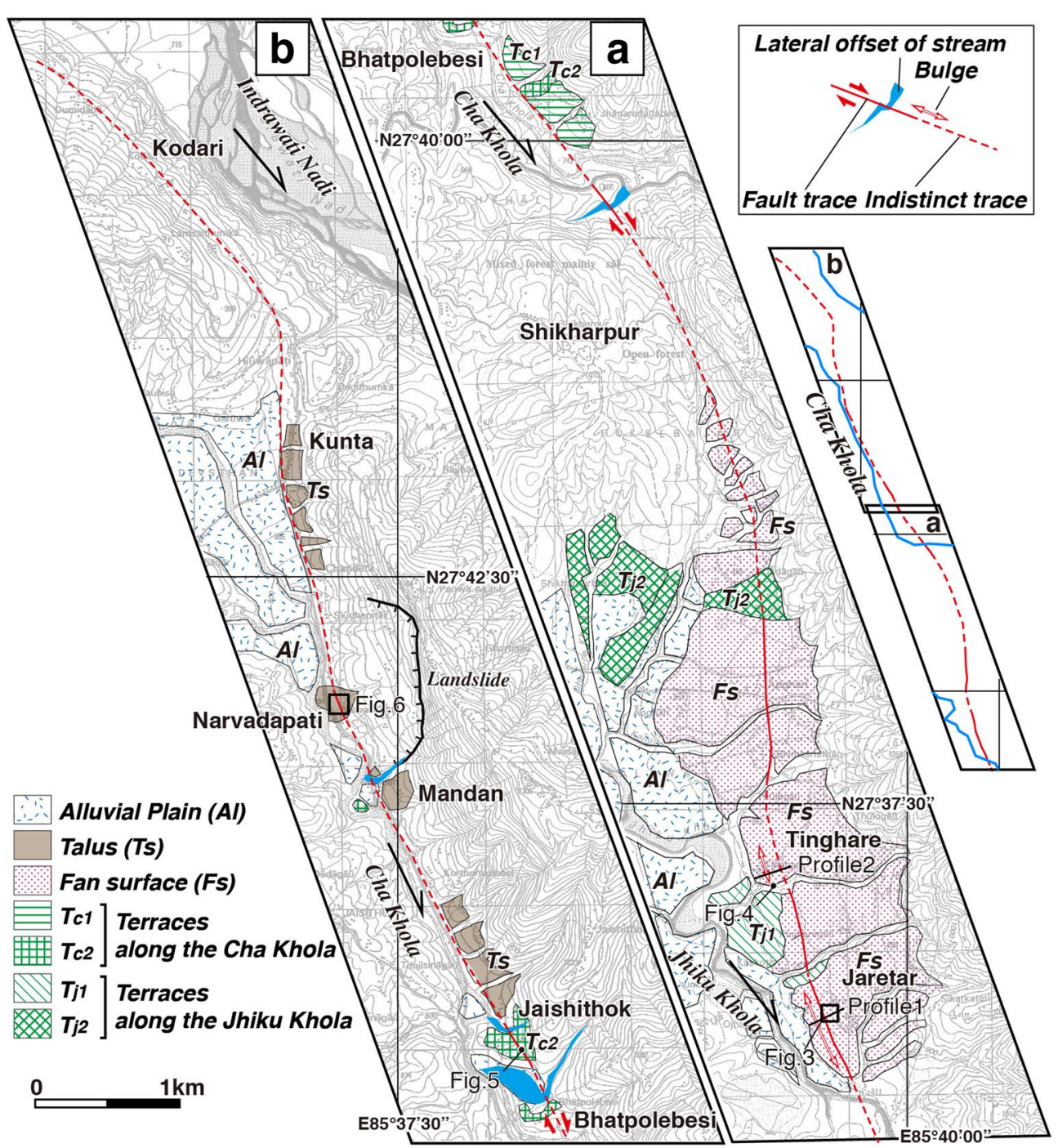

Fig. 2 a Geomorphic and fault trace map along the Jhiku Khola fault in southern part and $\mathbf{b}$ in the northern part 
Along the left bank of the Jhiku Khola, two levels of terraces, one at higher (Tj1) and another at lower (Tj2) level, and the colluvial fan surface (Fs) are observed, and the both terraces are covered with the Fs deposit yielding $16 \mathrm{ka}$ of age (Yagi et al. 2000). At Jaretar and Tinghare, the strikeparallel bulge and depression are observed on the lower part of the Fs surface, indicating that the fault movement has occurred during the Holocene. We made the detailed DSM image (Fig. 3a) here using the SfM-MVS software processing more than 200 sheets of photographs taken by the camera on the tip of the 10 -m-high pole (Fig. 3b). This image provided us with clear tectonic feature of the bulge and the depression. Here, we measured approximately $7.5 \mathrm{~m}$ vertical displacement due to the fault slip on Fs surface (Fig. 2c). The error of the measurement is $0.2 \mathrm{~m}$.

There is the north-trending bulge and depression at Tinghare. We considered two parallel faults in this area: one fault below the bulge as a thrust fault, and the other fault along the boundary between the bulge and the depression. The thrust fault below the bulge appears in the outcrop (Fig. 4a, b). The fault with $\mathrm{N}-\mathrm{S}$ trending and $45^{\circ} \mathrm{E}$ dip offsets the $\mathrm{Tj} 2$ terrace deposit and the Fs deposit. The long-term fault movement has played a role to uplift the bulge. As the length of the bulge is $500 \mathrm{~m}$ and the bulge is not observed toward the north, the thrust fault is regarded as a secondary fault. However, we could not find the geological evidence relating to the other fault along the boundary between the bulge and the depression; we regarded the fault as a main fault (Fig. 4c), because the trace is recognized as a continuous depression on the Fs terrace toward the north.

The right-lateral offsets of the stream were observed at north of Shikharpur, Bhatpolebesi, Jaishithok, Mandan and Narvadapati along Cha Khola (Fig. 2b). All the lateral offsets except north of Shikharpur are located on the left bank of Cha Khola and deflected toward the

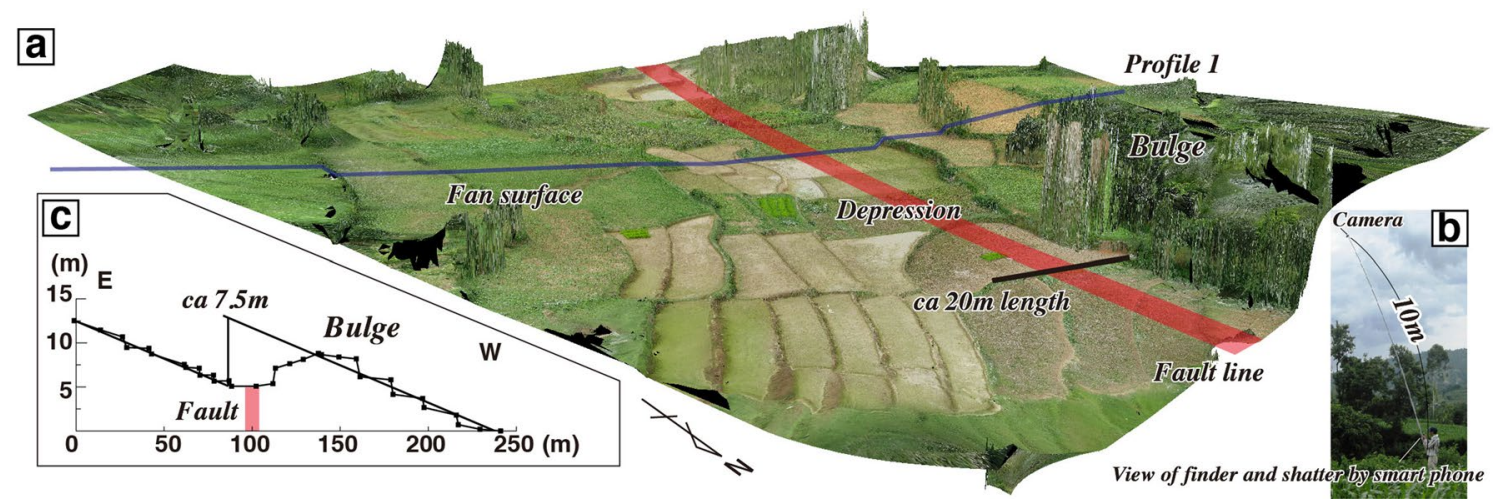

Fig. 3 a DSM image of the tectonic landform at Jaretar, $\mathbf{b}$ field photograph showing the method of taking photo by the camera on a 10-m-high pole for making the DSM image, c topographical profile across the deformed fan surface
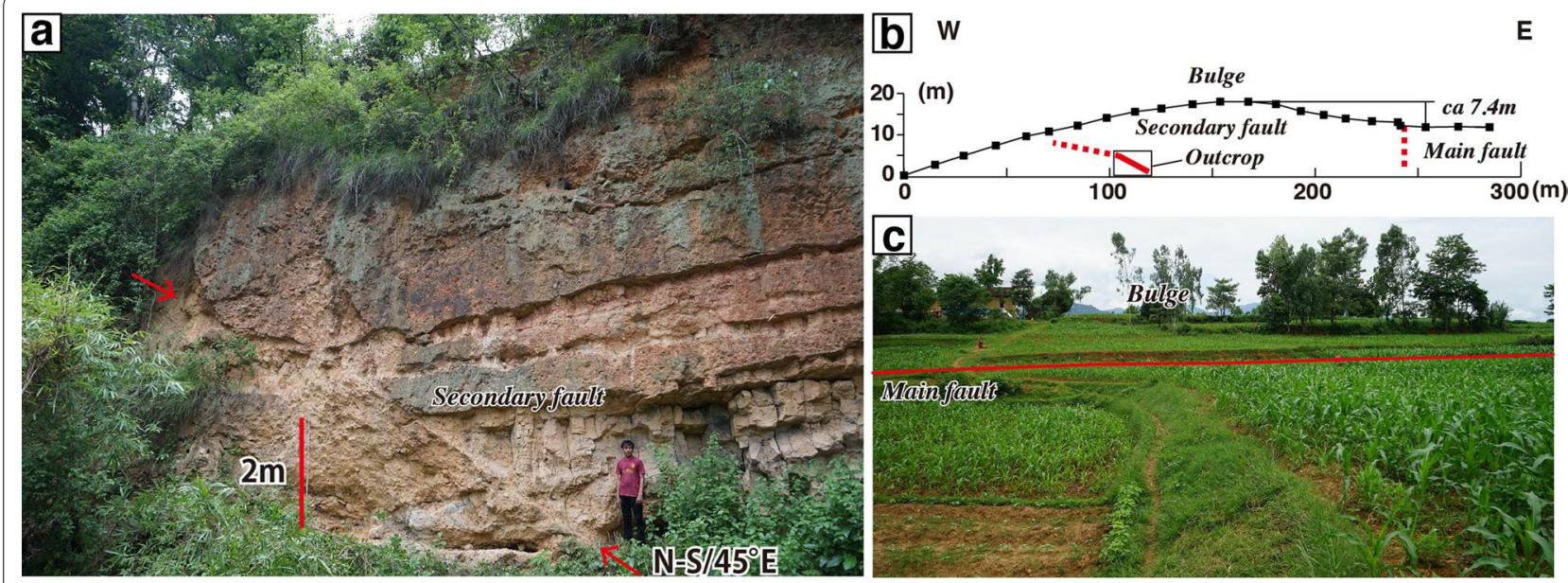

Fig. 4 a Photograph of the outcrop of fault plane in terrace deposit at Tinghare, $\mathbf{b}$ topographical profile across the deformed fan surface, $\mathbf{c}$ photograph of tectonic landform and presumed fault trace 
upper stream of Chu Khola, implying that the pattern of these offsets is uphill flowing and provides the sure evidence of active faulting. Along Chu Khola, we classified two levels of the terraces of higher one (Tc1) and lower one (Tc2), and Talus surfaces (Ts), and alluvial plain. On the Tc2 terrace riser at Jaishithok, we observed the fault plane with $\mathrm{N} 10^{\circ} \mathrm{W}$ trending and $80^{\circ} \mathrm{E}$ dip in the strongly weathered phyllite belonging to the Lesser

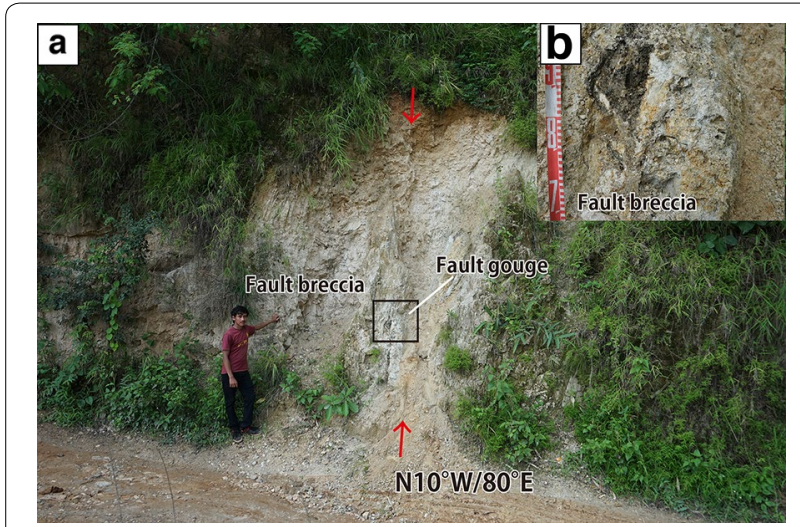

Fig. 5 a Photograph of the outcrop of fault plane in the bedrock (phyllite) at Jaishithok, b close-up photograph of fault breccia
Himalayan rocks (Fig. 5) and 2.2-m-wide fault breccia along the plane. At Narvadapati, a NNW-trending westfacing fault scarp has developed on the Ts surface, and the stream dissecting the surface shows right-lateral offset of approximately $7 \mathrm{~m}$ (Fig. 6a). There is an outcrop of the fault plane with $\mathrm{N} 30^{\circ} \mathrm{W}$ trending and $80^{\circ} \mathrm{W}$ dip in the phyllite rocks at the stream-offset site (Fig. 6b). We also found an exposure of the upper Ts deposit that is composed of slightly reddish clay with granule, and 20-cm-thick inclined granule bed within the clay deposit (Fig. 6c). The exposure is located more than $3 \mathrm{~m}$ above the stream, which dissected the Ts surface. A charcoal sample in the clay bed $50 \mathrm{~cm}$ below the top surface was collected for ${ }^{14} \mathrm{C}$ dating and yielded an age of $870 \pm 30$ y.B.P. (Beta-416339), implying that the Ts surface formed close to 870 y.B.P, and then, the stream initiated to dissect the Ts surface. Thus, either a single event or multiple events causing the 7-m offsets have occurred the last 870 years, and the slip rate we estimate roughly is around $8 \mathrm{~mm} /$ year. Since we could collect only one dating sample in Ts deposit and total stratigraphy of the Ts deposit was not known, this rate required to reexamine in the future. However, the slip rate of the previous study was only $0.5 \mathrm{~mm} /$ year (Yagi et al. 2000), and the slip rate could be faster than the previous one.
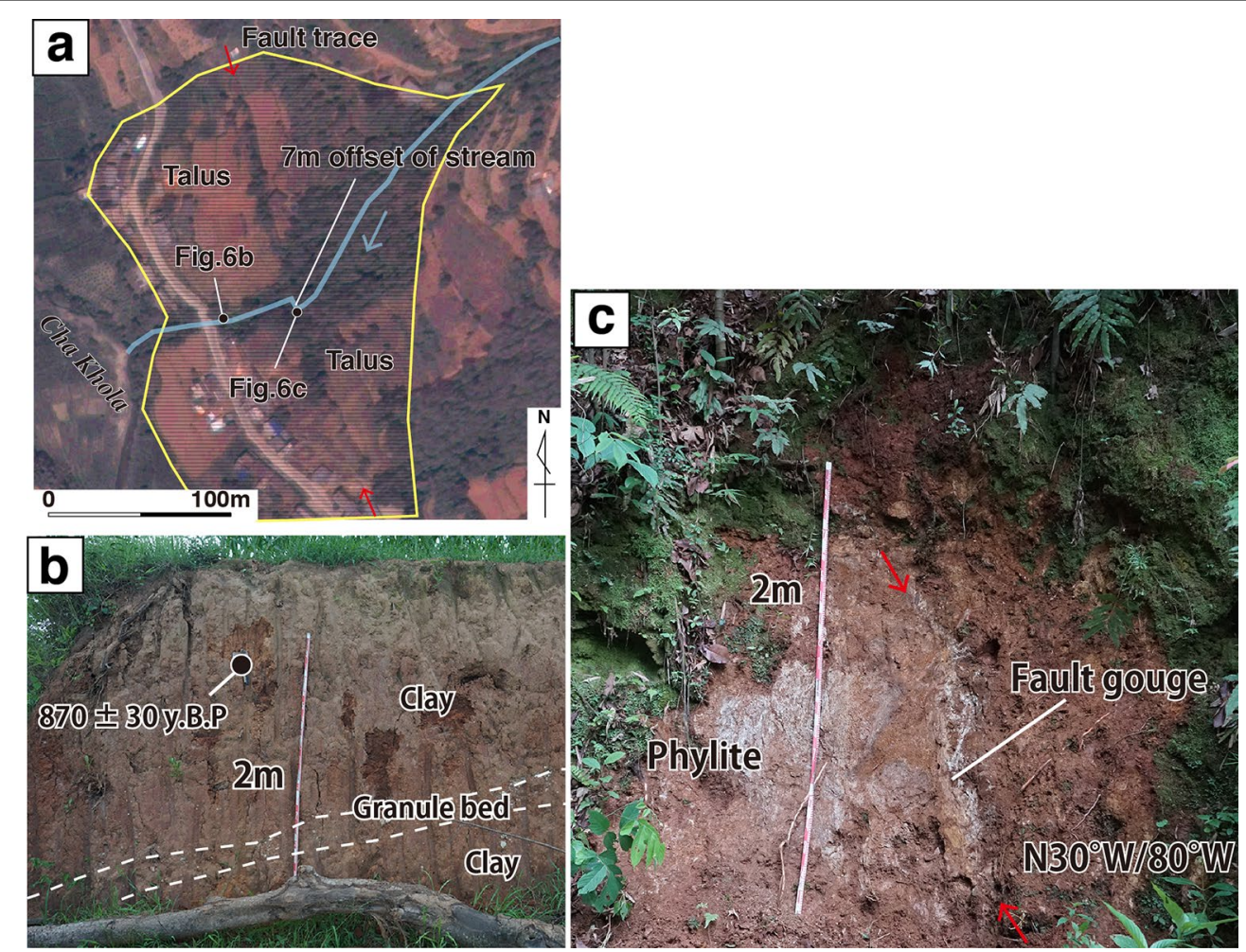

Fig. 6 a Geomorphic and fault trace map at Narvadapati, $\mathbf{b}$ photograph of the outcrop of talus deposit, c photograph of the outcrop of fault plane in the bedrock (phyllite) 
We surveyed more than 20 sites along the Jhiku Khola fault, but could not find any surface rupture as a result of the April 25 Gorkha earthquake; at the same time, there was no eyewitness account regarding the presence of any coseismic surface rupture.

\section{Kulekhani and Chitlang faults}

All the three NW-SE trending active faults, viz. Malagiri, Chitlang and Kulekhani faults, located on the southern side of the Chandragiri Mountain Range forming the southern boundary of the Kathmandu Valley, have their down-thrown side to the northeast (Nakata 1982; Yagi et al. 2000) (Fig. 7a). The fault lengths of the Malagiri fault, Chitlang fault and Kulekhani fault are 3.5, 7.3 and $10.2 \mathrm{~km}$, respectively. The Chitlang fault runs parallel to the 3-km-long gap zone between two other faults. Yagi et al. (2000) showed them as normal faults. Based on the displacement on faulted fan surface and the ${ }^{14} \mathrm{C}$ age of its deposit, we calculate the late Quaternary vertical slip rate of the Chitlang fault to be about $0.9 \mathrm{~mm} /$ year (Yagi et al. 2000). During the present survey, we surveyed three sites along the Kulekhani fault (Fig. $7 \mathrm{~b}-\mathrm{e}$ ) and one site along



Fig. 7 a Fault trace map of the Malagiri, Chitlang and Kulekhani faults, $\mathbf{b}$ far view of the fault scarp of the Kulekhani fault at Khuike, c close view of the fault scarp of the Kulekhani fault at Khuike, $\mathbf{d}$ far view of the fault scarp toward southeast at Kalinge, e close view of the fault scarp of the Kulekhani fault at Kalinge, $\mathbf{f}$ close view of the fault scarp of the Chitlang fault at Bisinkhel 
the Chitlang fault (Fig. 7f), and no coseismic surface ruptures were seen anywhere along the faults as a result of the 2015 Gorkha earthquake.

\section{Kolphu Khola fault}

This ENE-WSW trending fault is located on the right bank of the Kolphu Khola, a tributary of the Trisuli River flowing through the area to the northwest of the Kathmandu Valley (Nakata 1982) (Fig. 8). North-facing fault scarps on mountain slopes and the fluvial terraces observed along the fault, suggesting that vertical displacement is down on the north (Nakata 1982). Nakata et al. (1984) have shown this fault as the active normal fault based on the observation of outcrop of the fault plane. According to our survey, this fault is traceable for a length of $15 \mathrm{~km}$ and found that there are two right-lateral stream offsets along the trace of this fault. The mode of the fault may be not only normal faulting, but also right-lateral component. Future investigations relating to fault movement are needed. We surveyed most prominent and recognizable tectonic landforms along this fault around Ratatar, but no serious damage of houses near the fault scarp and no surface deformation were found, suggesting that no coseismic surface rupture has occurred on this active fault during the 2015 earthquake.

\section{Discussion and conclusion}

We show geological and geomorphological evidences of the late Quaternary activity of the active faults around the Kathmandu Valley, and no faults played any parts in triggering this large earthquake. Angster et al. (2015) claimed that no surface rupture along the trace of the HFT, the pattern of InSAR interferograms, focal mechanism and aftershock distribution of the event indicated that it was a low-angle thrust event on the MHT and the southern tip of the rupture ended below the mountain over $30 \mathrm{~km}$ north of the Gangetic plain. Our results also supported this idea.

The existence of an active fault reflects a potential seismic hazard for a shallow-depth earthquake around the fault. For example, the 2005 Kashmir earthquake $(\mathrm{Mw}=7.6)$ in Pakistan occurred on a previously mapped active fault (Nakata et al. 1991; Kumahara and Nakata 2006), and the fault produced an average event interval of $\sim 2$ k.y. for the 2005 earthquake type events (Kondo et al. 2008). In the present situation, it is difficult to evaluate the potential seismic hazard due to lack of paleoseismological data of those faults; however, it is needed to carry this study forward for assessments of the Kathmandu Valley.

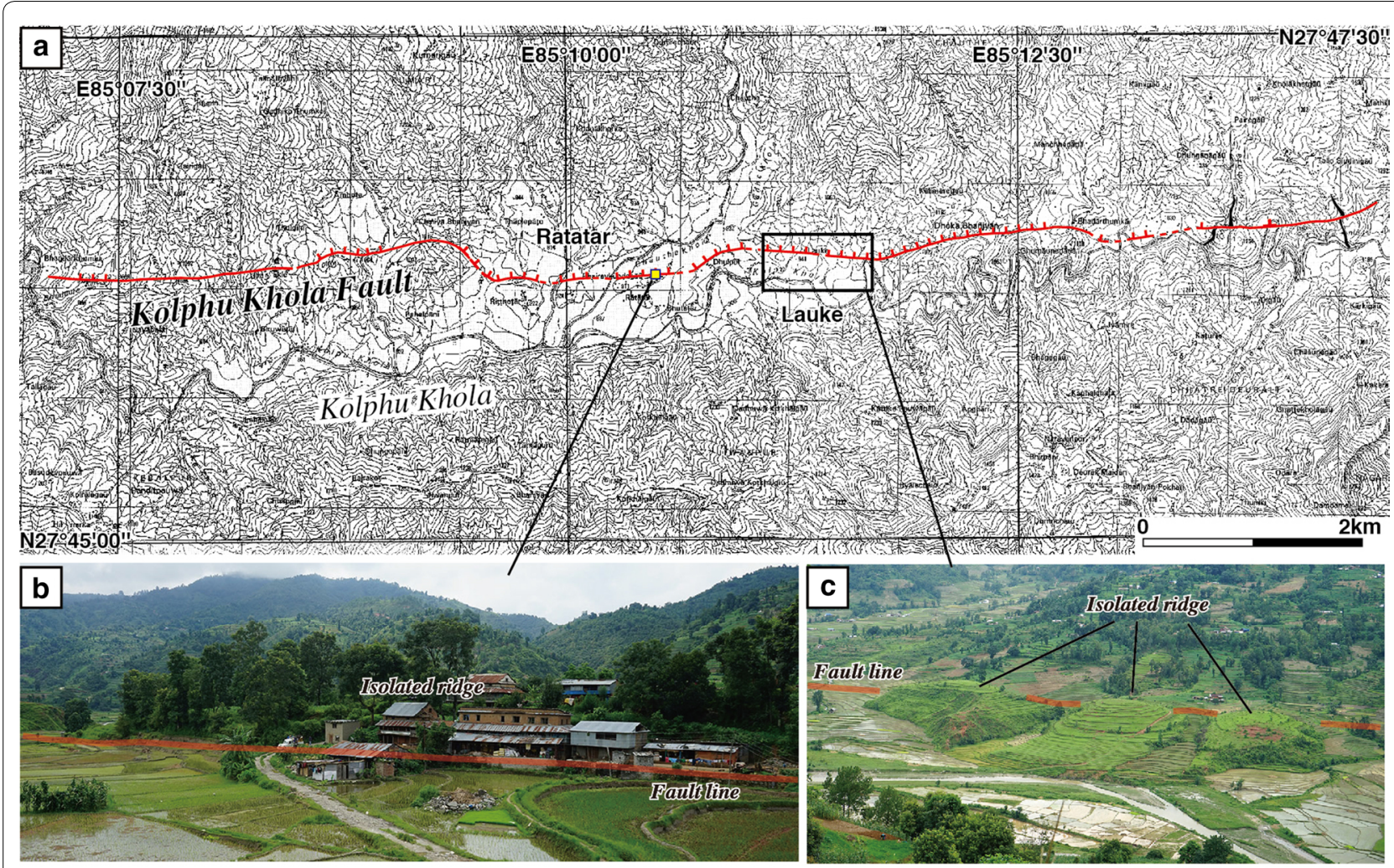

Fig. 8 a Fault trace map of the Kolphu Khola fault, $\mathbf{b}$ close view of the fault scarp of the Kolphu Khola fault at Ratatar, $\mathbf{c}$ far view of the tectonic landform along the Kolphu Khola fault 
The Jhiku Khola fault, which shows a right-lateral strike-slip movement with $8 \mathrm{~mm} / \mathrm{yr}$ of the slip rate, may play an important role in the active tectonics of the Himalayan range. Nakata (1989) claimed that an en-echeloned active right-lateral strike-slip fault system from northwest Nepal to eastern Nepal cuts obliquely across the Himalayan range due to slip partitioning, such that the block lying to the southwestern side of the fault moves northwestward with respect to the block lying to the northeastern parts. It is possible that the Jhiku Khola fault constitutes one of the members of this fault system.

\section{Authors' contributions}

YK planed and did all the fieldwork and wrote all the text and drew all the figures. DC discussed the interpretation of tectonic landform with YK and BU and interviewed the local people regarding to the surface rupture. BU discussed the interpretation of tectonic landform with YK and DC. All authors read and approved the final manuscript.

\section{Author details}

${ }^{1}$ Graduate School of Education, Hiroshima University, Higashi-hiroshima, Japan. ${ }^{2}$ Department of Geology, Tri-Chandra Multiple Campus, Tribhuvan University, Kathmandu, Nepal. ${ }^{3}$ Nepal Academy of Science and Technology, Lalitpur, Nepal. ${ }^{4}$ Present Address: Department of Geology, School of Mines, University of Zambia, Great East Road, P.O. Box 32379, Lusaka, Zambia.

\section{Acknowledgements}

This work was supported by Grant-in-Aid for Special Purposes for the 2015 Nepal Earthquake Disaster Emergency Survey Research Project by the Ministry of Education, Science, Sports and Culture, Japan to YK. We thank Bibek Giri and Upendra Bayal, who led us to support our fieldwork, and Stephen Angster, who provided us the basal map of Fig. 1. We are grateful to anonymous reviewers for providing valuable comments and suggestions, which helped us in improving the manuscript.

\section{Competing interests}

The authors declare that they have no competing interests.

Received: 30 October 2015 Accepted: 18 March 2016

Published online: 02 April 2016

\section{References}

Angster S, Fielding EJ, Wesnousky S, Pierce I, Chamlagain D, Gautam D, Upreti BN, Kumahara Y, Nakata T (2015) Field reconnaissance after the 25 April 2015 M 7.8 Gorkha earthquake. Seism Res Lett. doi:10.1785/0220150135

Asahi K (2003) Thankot active fault in the Kathmandu Valley, Nepal Himalaya. J Nepal Geol Soc 28:1-8

Goto H (2015) Mapping of fault geomorphology using "Structure from Motion-Multi-Video Stereo" photogrammetry with old/Hi-view aerial photography. Act Fault Res (Katsudanso-kenkyu) 42:73-83 (In Japanese with abstract in English)

Kobayashi T, Morishita Y, Yarai H (2015) Detailed crustal deformation and fault rupture of the 2015 Gorkha earthquake, Nepal, revealed from ScanSARbased interferograms of ALOS-2. Earth Planets Space 67:201. doi:10.1186/ s40623-015-0359-z

Kondo H, Nakata T, Akhtar S, Wesnousky S, Sugito N, Kaneda H, Tsutsumi $\mathrm{H}$, Khan A, Khattak W, Kausar AB (2008) A Long recurrence interval of faulting beyond the 2005 Kashmir earthquake around the northwestern margin of the Indo-Asian collision zone. Geology. doi:10.1130/G25028A.1

Kumahara Y, Nakata T (2006) Active faults in the epicentral area of the 2005 Pakistan earthquake. Special publication no. 41, Research Center for Regional Geography, Hiroshima University

Lindsey E, Natsuaki R, Xu X, Shimada M, Hashimoto H, Melgar D, Sandwell D (2015) Line of sight deformation from ALOS-2 interferometry: Mw 7.8 Gorka earthquake and 7.3 aftershock. Geophys Res Lett. doi:10.1002/2015GL065385

Nakata T (1982) A photogrammetric study on active faults in the Nepal Himalaya. J Nepal Geol Soc 2:67-80

Nakata T (1989) Active faults of the Himalaya of India and Nepal. Geol Soc Am Spec Pap 232:243-264

Nakata T, Iwata S, Yamanaka H, Yagi H, Maemoku H (1984) Tectonic landforms of several active faults in the western Nepal Himalayas. J Nepal Geol Soc 4:177-200

Nakata T, Tsutsumi H, Khan SH, Lawrence RD (1991) Active faults of Pakistan. Hiroshima University Research Center for Regional Geography, Special publication 21

USGS (2015) M7.8 - 36 km E of Khudi, Nepal. http://earthquake.usgs.gov/earthquakes/eventpage/us20002926\#general_summary. Accessed 31 Oct 2015

Wesnousky SG (2008) Displacement and geometrical characteristics of earthquake surface ruptures: issues and implications for seismic-hazard analysis and the process of earthquake rupture. Bull Seismol Soc Am 98(4):1609-1632

Yagi H, Maemoku H, Ohtsuki Y, Saijo K, Nakata T (2000) Recent activities of active faults distributed in and around Kathmandu valley, Lower Himalayan zone. In: Okumura K, Takada K, Goto H (eds) Proceedings of Hokudan international symposium and school on active faulting, Nojima Fault Preservation Museum, Hyogo 17-26 January 2000, pp 557-560

\section{Submit your manuscript to a SpringerOpen ${ }^{\circ}$ journal and benefit from:}

- Convenient online submission

- Rigorous peer review

- Immediate publication on acceptance

- Open access: articles freely available online

- High visibility within the field

- Retaining the copyright to your article

Submit your next manuscript at $>$ springeropen.com 